\title{
НАРОДНИЦТВО, МОДЕРНІЗМ І ПОСТМОДЕРНІЗМ У МЕДІЯХ
}

\author{
ТЕТЯНА МОНАХОВА \\ Чорноморський національний університет імені Петра Могили, Миколаїв — Україна \\ monakhovalist@gmail.com
}

NARODNICTWO, MODERNIZM I POSTMODERNIZM W MEDIACH

TETIANA MONACHOWA

Czarnomorski Uniwersytet Państwowy imienia Petra Mohyły, Mikołajów — Ukraina

STRESZCZENIE. Niniejszy artykuł poświęcony jest wyjaśnieniu pojęć "narodnictwo", "modernizm" i "postmodernizm" w świetle teorii komunikacji społecznej. Wymienione terminy rozpatrywane są jako strategie tworzenia tekstu w mediach i określane według następujących kryteriów: przynależności do gatunku, struktury tekstu, właściwości grupy docelowej oraz treści.

\section{PEOPLEISM, MODERNISM AND POSTMODERNISM IN MEDIA}

\author{
TETIANA MONAKHOVA
}

Petro Mohyla Black Sea National University, Mykolaiv — Ukraine

\begin{abstract}
This article is devoted to the understanding of the "peopleism", "modernism" and "postmodernism" concepts in the social communications theory. The above terms are considered as text- and media strategies and can be determined on several criteria: the genre affiliation, text structure, characteristics of the target audience, the subject content.
\end{abstract}

онцепція сучасних стратегій текстотворення ${ }^{1}$, що об’єднує народницьку,
модерністську і постмодерністську стратегії, знаходить свій розвиток
і в теорії соціальних комунікацій.
Під терміном стратегія текстотворення в лінгвістиці розуміємо культурно-соціальну позицію мовця, утілену в певних тенденціях добору й уживання мовних одиниць у його мовленні. Стратегія текстотворення $є$ явищем водночас як екстра-, так і інтралінгвістичним, тобто це спосіб організації повідомлень, що залежить від настанов мовця та його інтенцій під час говоріння, має чіткий вербальний план вираження, репрезентований певними прийомами і тактиками творення тексту, але й зумовлений законами розвитку мови. Стратегія текстотворення відображає свідоме ставлення мовця до стану, статусу й еволюції української мови, традиційної української концептосфери, мовних і культурних табу; це спосіб позиціонування себе, зовнішня самопрезентація через мову; це показник залученості мовця в соціально-культурний та політичний контексти або його відчуження від них. Вивчення стратегій текстотворення - це спосіб діагностування світоглядних позицій комунікантів і водночас результату відбиття менталітету мовців у їхньому мовленні.

Наявність i функціювання народницької, модерністської i постмодерністської стратегій текстотворення було виявлено на трьох рівнях: на рівні мовознавства, на рівні мови й на рівні мовлення.

\footnotetext{
${ }^{1}$ Т. В. Мон ахо в а, Народництво, модернізм і постмодернізм у лінгвістиці, Миколаїв 2015.
} 
Народництво, модернізм і постмодернізм у мовознавстві виявляються як три типи системних підходів до вивчення мови. Їхня відмінність полягає в таких параметрах:

- способах дослідження мови;

- суміжності / окремішності з іншими науковими дисциплінами;

- функційному призначенні лінгвістичної розвідки.

Мовознавче народниитво розмірковує про мову в межах класичної лінгвістики, застосовуючи традиційний термінологічний апарат; об'єктом i предметом народницької лінгвістики $\epsilon$ мова як така; найпоширеніші методологічні характеристики - описовість і прескриптивізм; мета таких студій - якнайповніша каталогізація та всебічний опис мовних систем.

Мовознавчий модернізм розвиває лінгвістику, виводячи іï на суміжні рівні 3 іншими науками; об'єктом є функціювання мови в соціумі, предметом міждисциплінарні зв'язки мови й мислення, мови й культури, мови та інших суспільних галузей; розгалужені складні терміносистеми, що можуть дублювати одна одну, інколи навіть суперечити; мовознавчий модернізм нерідко послуговується методами інших наук для вивчення мови; мета — вивчати мову як один з видів людської суспільної діяльності.

Мовознавчий постмодернізм “бачить” мову як інструмент, за допомогою якого здійснюються різноманітні процеси та явища у взаємодії між людьми; якщо народництво йде від мови й не виходить за ії межі, модернізм вивчає мову навпіл 3 іншими психо-соціальними факторами, то постмодернізм іде від екстралінгвістичних потреб і проблем до мови як до способу їхньої реалізації. Прикладний характер мови - найголовніша ознака лінгвістичного постмодернізму.

Народницька стратегія текстотворення на рівні мови характеризується україноцентричністю, вираженою в реанімації питомо української лексики, плеканні традиційних мовних стандартів, закритістю до запозичень та інтерференції, розвитком концептосфери „Україна - мова — патріотизм”; позначена мовним пуризмом і постколоніальним комплексом.

Модерністська стратегія текстотворення в українській мові відзначається великою кількістю запозиченої лексики; детабуюванням теми тілесності й введенням до активу мови згрубілої та лайливої лексики; європоцентричністю - збільшенням кількості лексем на позначення явищ і процесів, пов'язаних з Європою; основною інтенцією мовців-модерністів $\epsilon$ прагнення мовного авангарду й залучення української мови до світових тенденцій.

Постмодерністська стратегія текстотворення грунтується на принципі мовної гри, вдається до вербального епатажу й брутальності, застосовує некодифіковані форми української мови зі стилістичною метою, розвиває нові формати функціювання державної мови, зокрема мову Інтернету.

Народницька, модерністська і постмодерністська стратегії текстотворення в мовленні становлять сукупності індивідуальних вербальних виявів у кожному конкретному ідіолекті. Утім, ці вияви підлягають систематизації та узагальненню й можуть бути оформлені в мовленнєві тактики кожної зі стратегій. Описуючи узуально-стильові прикмети вживання мови на сучасному етапі, мовознавець здійснює аналіз з метою виявлення можливості контекстних модифікацій стилістичного значення, що в ньому закладені самою мовою, які беруть участь у створенні комунікативного стилістичного комплексу. 
Функції та наповнення цього комплексу залежать від обопільних зв'язків стилістичної мовної одиниці й контексту, у якому її вжито. Відправним пунктом опису мовленнєвих тактик $€$ категорія модальності в широкому лінгвістичному розумінні, а також категорія аксіології, тобто оцінки.

Як видно, термін стратегія текстотворення певним чином перегукується 3 терміном ідеологія, зафіксованим у словникові постмодерністських термінів: „Ідеологія - термін, що має в західних гуманітарних науках, зокрема в структуралістських і постструктуралістських колах, значення, дещо відмінне від його звичного узусу... У галузі цих наукових уявлень під ідеологією розуміють сукупність позначуваних конотацій чи вторинних позначуваних (в опозиції до риторики як системи вторинних позначуваних). Ідеологію виявлено (маніфестовано) як дещо, зрозуміле саме собою. Її «авторитет» грунтується на тому, що вона $\epsilon$ відношенням між «даним» нам дискурсом і топікою (загальною чи конкретною). Топіка буває конкретною, якщо йдеться про поняття, прийняті тільки в певному конкретному суспільстві, і загальною, якщо йдеться про поняття загальнолюдські. Дуже часто під цим терміном розуміють будьяку систему поглядів: побутових, сімейних, релігійних, політичних, естетичних тощо, відкритих і прихованих, що регулюють сферу повсякдення"2. Стратегія текстотворення, яку визначають світоглядні позиції та інтенції мовця, акумулює в собі все те, що вміщено в поняття ідеологія, але виводить цю систему поглядів зі сфери повсякдення на вищий ментально-соціальний рівень.

Якщо до базових критеріїв визначення стратегії текстотворення (інтенції мовця, індивідуальні мовленнєві особливості добору мовних одиниць і організації текстових повідомлень, світоглядні настанови, способи оцінювання тощо) додати соціокомунікативні, зокрема такі, як:

- цільова аудиторія,

- канал транслювання інформації,

- застосування текстових / аудіальних / відео- / візуальних форм організації повідомлення,

- контент,

- клікабельність тощо,

то концепцію стратегічного текстотворення можна почати осмислювати в медійній площині, а це, відповідно, розширює прикладне значення самої концепції, дозволяючи усвідомити закономірності еволюції та механізми реалізації ключових функцій мови в засобах масової комунікації.

Мета цієї розвідки - окреслити подальші вектори розвитку концепції стратегій текстотворення в контексті теорії медіа, висунути гіпотезу про співвіднесеність народницької, модерністської і постмодерністської стратегій текстотворення з епохами Web 1.0, Web 2.0, Web 3.0, з різними журналістськими жанрами й навіть проблемою стандартів сучасної журналістики.

Принципова відмінність між лінгвістичним осмисленням i медіавивченням стратегій текстотворення полягає в тому, що мовознавство досліджує народницьку, модерністську і постмодерністську стратегії текстотворення в умовах, коли породження тексту відбувається у векторі “від мовця до адресата": мовець застосовує мовлення для самопрезентації й досягнення власних комунікаційних цілей, тоді як у медіа текстотворення відбувається "від адресата до мовця" - цільова аудиторія de facto диктує, що, як і ким буде сказано.

\footnotetext{
${ }^{2}$ И. П. Ильин, Постмодернизм. Словарь терминов, Москва 2001, с. 54.
} 
Друге принципове застереження: медіанародництво, медіамодернізм і медіапостмодернізм не слід розглядати в суто діахронійному аспекті. Усі три явища функціюють синхронно, взаємодіють, корелюють, взаємовпливають, реалізуються пропорційно в сучасному медіапросторі.

У діахронійному зрізі медіанародництво - це перший етап розвитку медій, поява газетярства (ще раніше - поява книгодрукування, а ще раніше літописання, грамоти, укази тощо), виникнення й розвиток телебачення, i, зрештою, винайдення Інтернету, початковий немасовий період його використання.

Медіамодернізм виникає з появою соціальних мереж і групової роботи над інформацією. Медіапостмодернізм настає з епохою поширення Інтернет-медій.

За каналом передання інформації, медіанародництво - це паперове газетярство, теле- і радіомовлення, а також епоха Web 1.0, коли медії дублювали в Інтернеті друковану пресу. Розвиток блогосфери припадає на епоху Web 2.0, що співвідноситься з медіамодернізмом. Розвиток електронних 3МI, надзвичайне поширення Facebook, Twitter та інших соціальних мереж, перехід на мобільні платформи ознаменували епоху Web 3.0, що корелює з медіапостмодернізмом.

Історія розвитку журналістських жанрів також відбиває еволюцію медіанародництва, медіамодернізму і медіапостмодернізму. Уся палітра класичних жанрів журналістики становить народницьку стратегію в медіа. Майже всі ці жанри продовжують функціювати й в медіамодернізмі, й у медіапостмодернізмі, деякі - трансформувавшись, більшість - продовжуючи традицію. Зник лише один народницький журналістський жанр - так звана передовиця. Деякі, на кшталт памфлету чи портретного нарису, утрачають свою масовість, розвиваючись у модерністську напівблогову манеру розповіді (найчастіше це записи в блозі про подорожі, що охоплюють і опис людей, країн тощо). Найбільш незмінним і незмінно актуальним лишається есей, використовуваний як медіанародництвом, так і медіамодернізмом і медіапостмодернізмом.

Медіамодернізм розвиває класичні жанри народництва, водночас генеруючи нові. Так, поява телемостів, а згодом - онлайн-трансляцій спричиняє пошук нових форм подачі інформації в ефірі. 3'являються блоги і мікроблоги. Активно починають використовувати ідеографіку, що не $\epsilon$ винаходом власне медіамодернізму, - вона виникла задовго до появи Інтернету, утім набувши актуалізації саме в період модернізму. Найпопулярнішим жанром стає новина або розширена новина - новина, оздоблена коментарем і елементом аналітики. Цільова аудиторія перестає потребувати роз'яснень, вона вимагає новин.

Ця вимога — якнайшвидше отримувати якнайточнішу інформацію у медіапостмодернізмі виливається в цілковито новий жанр - стрім (Live Streaming), мультимедійний жанр для висвітлення гарячих подій, трансляція подій у реальному часі за допомогою зйомки “з рук”. Кліпове мислення нової генерації споживачів інформації зумовлює зменшення актуальності long read'iв. Популярними жанрами стають компілятивна стаття (через швидкісність Інтернет-3МІ й постійне оновлення контенту) і рейтинг (“10 найкрасивіших міст України”, "15 причин схуднути" тощо). Такі форми організації та споживання інформації зручні як для медівників, тобто виробників інформації, так і для користувачів, читачів контенту.

Facebook- i Twitter-сторінки найбільш популярних користувачів соцмереж набувають статусу засобів масової комунікації, виконуючи ті самі функції, що й традиційні 3МI. 
Зрештою, з'являються цілком постмодерністські навіть за лінгвістичними мірками жанри: фотожаба, скрімер, рейдж-комікс тощо. Фотожаба - ілюстрована карикатура, як правило, створена технікою колажу, накладанням саркастичних підписів на фотокадри з популярних фільмів, теленовин тощо. Скрімер (від анг. Screamer - крикун, вигукач, шокер) - це різновид Інтернет-контенту, створений для шокування користувачів. Рейдж-комікс (від англ. Rage Comics) серія веб-коміксів, персонажів яких намальовано в найпростішому графічному редакторі без уваги до деталей, схематично. Усі ці малі й швидкоплинні жанри можна об'єднати спільною назвою - віртуальний візуальний креатив. Цей масив медіа-інформації грунтується на загальних постмодерністських принципах мовної гри.

Мовна гра - різновид загальної ігрової тенденції в суспільстві. 3 появою та розвитком Інтернету ця форма спілкування стає обов'язковою, за промовчанням, так би мовити. Мовну гру розуміють як варіювання плану вираження й плану змісту мовних знаків навіть до порушення норм на різних мовних рівнях 3 метою самовираження та емоційного впливу на адресата й отримання задоволення від мовної імпровізації. Як зазначає Г. Хазанов, гра - принципово важлива категорія для всього постмодерну, вона створює поле для його існування, саму можливість поєднання непоєднуваних начал ${ }^{3}$.

Постмодернізм розвиває естетичний плюралізм і амбівалентність на всіх рівнях творення тексту - сюжетному, композиційному, образному, мікроструктури, хронотопу тощо в художньому дискурсі; повноту уявлень без оцінок, культурологічну мету прочитання і співтворчість мовця та реципієнта, синкретизм, міфологічність мислення (що поєднує історичні й метафізичні категорії), творче використання будь-яких традицій, ігнорування причинно-наслідкових зв'язків під час конструювання текстів, опертя на принцип гри в усіх типах дискурсу4 ${ }^{4}$ Так, гра як соціально-комунікативна дія стає рушійною силою творення постмодерністських текстів.

Поняття "авторство" також зазнає видозмін залежно від стратегій текстотворення. Зокрема, у медіанародництві особистість журналіста $є$ вагомим чинником довіри до преси, соціальний статус журналіста $є$ високим, престижність професії значна. У медіамодернізмі дописи в Інтернеті $є$ анонімними, особа автора повністю нівелюється, важливим є полілог і колективне текстотворення. Медіапостмодернізм знову повертається до цінності авторства, анонімні й фейкові акаунти в соціальних мережах не вітаються, вони навіть заборонені правилами; з іншого боку, Інтернет-цитування часто нехтує авторським правом, тож постулат Барта “Автор помер” стає як ніколи актуальним.

Складники журналістського тексту також мають певні особливості залежно від стратегії текстотворення.

Народницький заголовок завжди характеризується художністю, образністю, певним пафосом, може не розкривати і ніяк не натякати на тему статті. Модерністський заголовок має прямий стосунок до теми, утім можливе застосування прийому інтриги. Постмодерністський заголовок має єдину вимогу - клікабельність: користувач Інтернет-ЗМІ повинен зацікавитися заголовком і натиснути на посилання. Тому постмодерністські заголовки максимально привабливі, гострі, несподівані, однак не мають повністю розкривати новину,

${ }^{3}$ Г. Н. Хазан ов, Мулен Руж: опыт текстуального анализа, [в:] „Язык. Текст. Дискурс”, науч. альманах Ставропол. отд-ия РАЛК, Ставрополь 2007, вып. 5, с. 176.

${ }^{4}$ О.В.Пронкевич, О.О.Старшова та ін., Сучасна американська література: проблеми вивчення та викладання, навч. посіб., Миколаїв 2002, с. 56 
про яку йдеться - читач може не пройти за посиланням, зрозумівши сутність повідомлення. Отже, в медіапостмодернізмі мистецтво заголовка, неймінг, виходить на перший план, оскільки від заголовка залежить кількість переглядів журналістського матеріалу.

Лід як традиційний компонент статті в медіанародництві є обов'язковим, грунтовним, змістовим складником матеріалу. Лід розкриває тему, готує читача до аналізу, виконує функцію вступу. У медіамодернізмі лід суттєво скорочується. Модерністські медіатексти читають користувачі Інтернету, які звикають швидко читати матеріали, особливо не занурюючись у написане, економлячи свій час. У медіапостмодернізмі ліди зникають, як, власне, i long read'и, необхідність введення в тему відпадає, оскільки жанр новини, найпопулярніший у медіапостмодернізмі, не потребує попередніх коментувань. Якщо лід залишається, він виконує не інформативну, а емотивну функцію мови, його завдання - затримати увагу читача, який клікнув заголовок.

Сама будова й наповнення тексту журналістського матеріалу залежить від обраної автором стратегії текстотворення. Класичні канони текстотворення, правила функціювання публіцистичного стилю мовлення, лінійна або фабулярна схема викладу матеріалу - усе це ознаки медіанародництва на текстовому рівні.

Медіамодернізм експериментує з текстовими формами. Починається відхід від канонів і навіть журналістських стандартів. Формула "News no views" потребує уточнення. Колумністика і публіцистика - ось медіамодерністські формати подання інформації. Журналіст, автор тексту, висловлює власні оцінки, коментуючи повідомлення, відкрито демонструє своє ставлення до сказаного. Проблема непохитності стандартів журналістики, незалежно від суспільнополітичних умов, стає предметом публічних обговорень і наукових конференцій в галузі соціальних комунікацій.

Медіапостмодернізм у своїй боротьбі з long read'ами за увагу читачів продукує новий текстовий тип - мультимедійні історії, підсилюючи власне текст візуальними й акустичними засобами.

Утім, найсуттєвішим критерієм визначення медіанародництва, медіамодернізму і медіапостмодернізму залишається тип цільової аудиторії. У маркетингу й рекламі під терміном “цільова аудиторія" розуміють групу людей, об'єднаних спільними ознаками (віковими, соціально-демографічними тощо) або об'єднаних заради однієї цілі. Соціально-демографічні ознаки певною мірою впливають на тип мислення, тобто вік, стать, професія, віросповідання це ті важелі, що формують комунікацію.

Термін “народництво” традиційно був літературознавчим, ширше культурологічним і соціально-політичним. Його змістове наповнення точно визначила С. Павличко: „Народництво - центральний термін української інтелектуальної історії, політики й культури - включає в себе широке коло понять. По-перше, народництво є політичною ідеологією... як правило, літературне народництво було генетично пов'язане 3 політичним і в свій спосіб його продовжувало. По-друге, народництво $\epsilon$ способом художнього існування літератури, стилем або системою стилів. По-трете, народництво $\epsilon$ способом теоретичного осмислення культури, формою ï критики, культурним дискурсом"5. Відштовхуючись від такого розуміння й спираючись на нього, починаємо розмірковувати про мовні прикмети носія народницької

${ }^{5}$ С.Д. Пав и и ко, Дискурс модернізму в украйнській літературі, Київ 1999, с. 28-29. 
ментальності, народницької позиції, народницького світогляду. Підгрунтям для широкої теорії народності слугує нативізм - прив'язаність до рідного місця, гомогенність культури, закоріненої в землю, традиції і мову, а також ототожнення “натуральної” (органічної) держави з народом, що має власну національну форму і власну мову. Сам термін "народництво” в літературознавстві $є$ досить дискусійним i, певною мірою, дискредитованим. Його семантичне наповнення містить значення, еквівалентні поняттям "хуторянство", “котляревщина", "холізм" тощо. Наголошуємо на тому, що мовознавче розуміння й медіаосмислення народництва стоїть осторонь таких тлумачень, спираючись передовсім на класичність як таку.

Імператив - одна 3 провідних категорій народницької стратегії текстотворення. Це пов'язано 3 інтенціями повчальності та моралізаторства. Серед граматичних ознак народництва - переважання множини особового займенника першої особи над одниною, “ми” замість “я", говоріння від імені більшості, громади. Інший маркер - постколоніальний комплекс: гостре реагування на непатріотичне ставлення співгромадян до історії країни, іiі сучасного політичного вектору тощо.

Поряд 3 традиційними народницькими темами в літературі, провідною темою ідіолекту носія народницької ментальності є тема України, іiі історії, патріотичності. Україноцентричність - засадничий принцип народництва. Концептосферу народництва в мові утворюють конгломерати семантичних полів “народ”, “Україна”, “доля”, “свобода”, “українська мова” тощо. Найважливішим завданням народників як психо-соціального типу людей $\epsilon$ відстоювання державної незалежності України в усі часи. Ретроспекція цього процесу, аналіз результатів (від здобутків до поразок) - перманентні теми народницького дискурсу. Говорити про державність - часто означає й створювати іiі саму.

На рівні мови - мовний пуризм, неприйняття моди на лексичні запозичення, калькування тощо; табуювання певних тем і сакралізація інших, фольклорність дискурсу, традиційна риторика.

Цільова аудиторія медіанародництва - це, очевидно, такі соціальні групи:

1. Консерватори, прихильники традицій, українських цінностей тощо.

2. Літні й зрілі люди.

3. Свідомі патріоти України всіх вікових груп.

Цільова аудиторія медіамодернізму випливає з розуміння самого терміна “модернізм". Модернізм зазвичай тлумачать широко. Це поняття, завжди зорієнтоване на західну інтелектуальну модель, включає європеїзм, або західництво, сучасність, інтелектуалізм, антинародництво, індивідуалізм, фемінізм, зняття культурних табу, зокрема у сфері сексуальності, деканонізацію національних знакових постатей і явищ, формалізм тощо.

У модернізмі виділяють і філософське підгрунтя, що декларує пріоритети мистецтва над мораллю, історією чи реальністю, що об'єднує всі тексти, продуковані цією стратегією, і становлять мистецькі течії естетизм, декаданс, імпресіонізм, неоромантизм. Такий філософський погляд на мораль та історію відчиняє двері табуйованій досі лексиці й темам. Модернізм звільняє мову від заборон й обмежень, дозволяючи використовувати в мовленні абсолютно все, що наявне в людській мові.

Якщо народництво - це традиційний патріархальний патріотичний український дискурс, то модернізм — це відкритість до запозичень (від куль- 
турних до мовних), руйнування штампів попередніх епох, активізація жіночого дискурсу та гендерних студій загалом тощо.

Витоки модернізму вбачають у прагненні митців (адресантів) створити новий тип тексту для впливу на читачів (адресатів): „У прагненні збагнути нову реальність митці відмовилися від принципів реалізму, що в нових обставинах виявився неадекватним методом. Почалися численні експерименти 3 формою. Т. Еліот замість наративного методу запропонував для модерного мистецтва міфологічний, що, на його думку, здійснив Дж. Джойс. Міф мав стати основою єдності художнього тексту, яку модерністський твір часто втрачав у пошуку глибшого й ширшого відображення складності життя"б.

Імовірно, цільова аудиторія медіамодернізму — це такі соціальні групи:

1. Представники креативних професій. Космополіти.

2. Люди, які активно займаються розвитком своєї кар'єри (30-45 років).

3. Люди, які мають можливість мандрувати або мають бізнес-контакти в інших країнах.

Постмодернізм $€$ чи не найуживанішим терміном багатьох наук сьогодення. У славістиці усталилася думка про те, що постмодернізм - це конгломерат теоретичних шкіл: постструктуралізм, деконструктивізм, рецептивна естетика, герменевтика.

Постмодернізм, на відміну від модернізму, нічого не заперечує, не дискутує, не виборює. Постмодерністська стратегія текстотворення лише відбиває мовну екзистенцію людини, виявляє іï самовираження через слова, дає змогу провадити принцип мовної гри в усьому, сприяє створенню ефектів від мовлення, зокрема таких, як епатаж чи захоплення слухачів.

Постмодерністська свідомість (менталітет) антидогматична та плюралістична, іiі головна прикмета й внутрішнє джерело руху — сумнів, відмова від альтернативного вибору “або - або” на користь широкого спектру рівноправних рішень “i - i”. Децентрація, або поліцентризм, тобто множинність, посідає місце провідної умови як суспільного, так і художнього існування. Тому, не надаючи переваги жодним традиційним художнім моделям, постмодернізм здатний брати з будь-яких духовних надбань. Разом з тим, тотальна іронічність погляду не тільки відрізняє постмодернізм від попередніх етапів у культурі та естетичному розвитку, а й не дає змоги вдаватися до пафосу, забезпечує об'єктивність оцінок і створює передумови для подальшого вибору․

Цільовою аудиторією медіапостмодернізму, очевидно, є такі соціальні групи:

1. Молодь.

2. Активні користувачі Інтернету.

3. Аполітичні соціальні прошарки.

Згідно з нашою гіпотезою, припускаємо, що, дослідивши весь медіаринок України, можна отримати карту розподілу засобів масової інформації та засобів масової комунікації відповідно до народницької, модерністської і постмодерністської стратегій текстотворення. Розподіл цей грунтуватиметься на тематичній специфіці видань (програм), особливостях цільових аудиторій, політичних поглядах редакції тощо. Ця гіпотеза потребує ретельної перевірки на великому масиві фактичного матеріалу, що й становить перспективу наших подальших досліджень.

\footnotetext{
${ }^{6}$ Там само, с. 17.

${ }^{7}$ О. В. Пронкев ич, О. О. Ст аршов а, зазнач. джер., с. 55.
} 